\title{
Effect of Foliar Application of Micronutrients on Plant Growth and Seed Germination of Four Okra Cultivars
}

\author{
Ghadir MOHAMMADI ${ }^{1}$, Ebrahim M. KHAH ${ }^{1}$, Spyridon A. PETROPOULOS ${ }^{1 *}$, \\ Dimosthenis B. CHACHALIS ${ }^{2}$
}

\author{
${ }^{1}$ University of Thessaly, School of Agricultural Sciences, Crop Production and Rural Environment, Fytokou Str. Nea Ionia, Volos 38446, \\ Greece;mohammadighadir@gmail.com;ekhah@uth.gr;fangio57gr@gmail.com(*correspondingauthor) \\ ${ }_{2}^{2}$ BenakiPhytopathological Institute,Stefanou Delta8,Kifissia 14651, Athens,Greece; d.chachalis@bpi.gr
}

\begin{abstract}
In the present study, the effect of foliar application of micronutrient fertilizers on okra plants was examined. Four okra cultivars ('Boyiatiou', 'Veloudo', 'Clemson' and 'Pylaias') were sprayed weekly throughout the duration of the cultivation with two commercial micronutrient fertilizers $\left(F_{1}\right.$ and $\left.F_{2}\right)$ [e.g. $M_{1}=$ control $(0 \mathrm{ml}) ; M_{2}=40 \mathrm{ml}(20 \mathrm{ml}$ of each fertilizer $) ; M_{3}=80$ $\mathrm{ml}$ ( $40 \mathrm{ml}$ of each fertilizer). From the results of the present study, it was observed that plant height of 'Boyiatiou' and 'Pylaias' was increased by application of $\mathrm{M}_{2}$ whereas plant height of 'Clemson' and 'Veloudo' was either unaffected or reduced. Flower induction increased at both micronutrient levels $\left(\mathrm{M}_{2}\right.$ and $\left.\mathrm{M}_{3}\right)$ only in 'Pylaias'. Pod set was higher in treatment $\mathrm{M}_{3}$ in 'Veloudo' and 'Pylaias' and resulted in higher seed yield. Pod length and diameter were not affected by micronutrient application, as well as 100-seed mean weight and moisture content; however the number of seeds per pod in 'Pylaias' was significantly lower in $\mathrm{M}_{2}$ and $\mathrm{M}_{3}$ than in $\mathrm{M}_{1}$, whereas the percent seed germination of all cultivars was higher following micronutrient application. Germination differed between the control and the micronutrient treatments at all times of harvest and plant parts. In conclusion, the main value of foliar application of micronutrients was to increase germination percentage and reduce hardseedness, especially for cv. 'Veloudo', since the occurrence of hard seeds in susceptible cultivars reduces germination, and therefore seed quality. In some cultivars ('Pylaias' and 'Veloudo' here) micronutrients may also increase seed yield by increasing pod set.
\end{abstract}

Keywords: Abelmoschus esculentus L., fertilizers, foliar spraying, seed germination, seed quality

\section{Introduction}

Foliar fertilization with multi-nutrients to achieve balanced plant nutrition is considered to play a significant role in modern sustainable vegetable production. This mode of applying fertilizers to the crops provides a valuable supplement to the application of nutrients via the soil (Fageria et al., 2009) and a number of studies have highlighted the benefits of foliar fertilization in improving plant growth, crop yield, nutrient uptake and product quality (El-Aal et al., 2010; Zodape et al., 2011). The particular value of this technique is that it ensures immediate uptake and translocation of nutrients to various plant organs via the leaf tissues and thus enables rapid correction of nutrient deficiencies (Fageria et al., 2009). Moreover, foliar fertilization has been recommended for integrated plant production since it not only increases crop yield and quality but is also environmentally safe (Fageria et al., 2009; El-Aal et al., 2010; Zodape et al., 2011).
Husain et al. (1989) reported that foliar application of iron in the form of ferrous ammonium citrate $(0.1 \%)$ along with $\mathrm{Zn}$ and B (0.1\%) increased the height of chilli plants, while Hooda and Pandita (1982) found that the foliar application of Agromin product $\left(\mathrm{ZnSO}_{4}, \mathrm{MnSO}_{4}, \mathrm{FeSO}_{4}\right.$ and $\left.\mathrm{CuSO}_{4}\right)$ at $1 \mathrm{~kg}$ per ha to potato also increased plant height. Tamilselvi et al. (2002) studied the effect of foliar application of micronutrients on the growth and yield of tomato. They reported a significant increase in plant height due to the application of $\mathrm{Cu}(100 \mathrm{ppm})$. Similarly, Palaniappan et al. (1999) reported that three sprays of Polyfeed product (19:19:19, Fe 1000 ppm, Mn 500, B-200, Zn$150, \mathrm{Cu}-110$ and $\mathrm{Mo} 70 \mathrm{ppm}$ ) increased the number of fruits per plant in chilli, while Tamilselvi et al. (2002) reported that foliar application of iron combined with other micronutrients ( $\mathrm{Zn}, \mathrm{Cu}, \mathrm{Mn}, \mathrm{B}$ and $\mathrm{Mo}$ ) in Multiplex product (100 ppm) significantly increased the number of fruits per plant of tomato. 
Abbasi et al. (2010) evaluated the growth and yield response of okra to three newly introduced foliar fertilizer products and their results endorsed the benefits of foliar fertilization by improving growth traits of the plants, viz. plant height, number of fruits plant per plant and fruit length. Similarly, Suryanarayana and Rao (1981) studied the effect of foliar application of iron on the growth of okra and found that the application of iron together with $\mathrm{Zn}, \mathrm{Cu}, \mathrm{Mn}$, $\mathrm{Mg}, \mathrm{B}$ and $\mathrm{Mo}$ in a chelated form (Agromin) resulted in increased plant height.

Knowledge of the right amounts of micronutrients required by the crop for optimum growth is not only important for the fresh produce but also for seed production. It is also useful to understand the fruiting behaviour of okra crop in relation to nutrient supply, since the concentration of mineral in the plant tissues affects growth and reproductive potential to a large extent (Majanbu et al., 1986). Therefore, in this study the effect of micronutrient application to the foliage on okra plants was examined with respect to the yield and quality of the pods and seeds in relation to harvest time and the position of the pods on the plant.

\section{Materials and Methods}

\section{Plant material and experimental conditions}

The experiment was carried out at the experimental farm of the University of Thessaly, Greece throughout the growing season of 2011. The soil texture was SCL (48\% sand, 29\% silt and $23 \%$ clay). The $\mathrm{pH}$ of soil was between 7.7- 8.1 and the organic matter was $1.44 \%, \mathrm{EC}=2.47 \mathrm{dS} / \mathrm{m}, \mathrm{CaCO}_{3}=2.80 \%$ (total) and P Olsen $=122 \mathrm{mg} \mathrm{Kg}^{-1}$. Seeds of four okra cultivars were sown in seeding trays on 20 May and retained in the nursery under controlled temperature (about $20^{\circ} \mathrm{C}$ ) until field transplantation. Plants were transplanted at the stage of 3-4 true leaves on 10 June. The climatic conditions throughout the experiment are presented in Fig. 1. Pods were harvested from mid-August to late October.

The experimental treatments were as follows: a) Four different cultivars of okra, cv. 'Clemson', 'Boyatiou', 'Veloudo' and 'Pylaias', b) Three micronutrient levels: $\mathrm{M}_{1}=$ control $(0 \mathrm{ml}$ micro nutrient); $\mathrm{M}_{2}=40 \mathrm{ml}$ micro nutrient $(20 \mathrm{ml}$ of each fertilizer); $\mathrm{M}_{3}=80 \mathrm{ml}$ micro nutrient ( $40 \mathrm{ml}$ of each fertilizer). The micronutrients were dissolved in $10 \mathrm{l}$ water and sprayed to run-off on the plant on a weekly basis, as far as possible taking care to avoid drift. Micronutrients were provided by IKOHYDRO and COMPO Companies under the commercial names of 'Proten' (Fertilizer 1; $F_{1}$ ) and 'Basfoliar 36 Extra' (Fertilizer 2; $F_{2}$ ). Although these products are marketed as sources of micronutrients, 'Proten' also contains $\mathrm{P}$ and $\mathrm{K}$ and 'Basfoliar' contains N. More specifically: 'Proten' fertilizer contained: $\mathrm{N}: 3.1$; Amino acid: $20.5 \%$; Phosphate $\left(\mathrm{P}_{2} \mathrm{O}_{5}\right): 3.8 \%$; Potassium $\left(\mathrm{K}_{2} \mathrm{O}\right)$ : 2.4\%; Calcium $(\mathrm{CaO})$ : 0.095\%; Magnesium $(\mathrm{MgO}): 0.48 \%$; Sulphate $\left(\mathrm{SO}_{4}\right): 1.43 \%$; other miconutrients (BFe-Mn-Zn): 0.24\%. 'Basfoliar 36 Extra' fertilizer contained: N: 27.0\%; MgO: 3.0\%; Mn: 1.0\%; Cu: 0.27\%; Fe: 0.027\%; B: 0.027\%; Zn: 0.013\%; Mo: 0.005\%).

A base dressing was not applied and the only fertilizers applied during growth were the micro nutrients. The crop was irrigated regularly on a weekly basis with a drip irrigation system, whereas for weed control Fusilade herbicide (fluazifop-P-butil, $800 \mathrm{ml} / 1000 \mathrm{~m}^{2}$ ) was implemented when needed.

Anthesis was first recorded 33 days after transplantation (DAT). Each flower was tagged on the day of anthesis and recorded in relation to its position on the plant etc.
Harvesting was carried out at the following harvest times: $\mathrm{T}_{1}=30 \mathrm{DAA}$ (days after anthesis), $\mathrm{T}_{2}=35 \mathrm{DAA}, \mathrm{T}_{3}=40 \mathrm{DAA}$, $\mathrm{T}_{4}=50 \mathrm{DAA}$. The same plants were randomly used for the different harvest times and were not placed in individual subplots.

\section{Measurements}

Throughout the experiment the following data were recorded: seed germination, total flower induction per plant, number of pod set per plant, pod length, pod diameter, average number of seeds per pod, 100 seed weight, plant height, 100 seed weight (determined after air-drying of seeds).

Seed germination was measured using 400 seeds per treatment, with four replications of 100 seeds each (ISTA, 2009). Seeds were surface sterilized with mancozeb fungicide prior

to the test, then placed on a double layer of Whatman No.1 filter paper moistened with distilled water in sterilized Petri dishes. The Petri dishes were placed in an incubator at $25^{\circ} \mathrm{C}$ for 21 days and every 2 days germinated seeds were counted and removed; in case of moisture deficiency distilled water was added. The criterion for germination was the emergence of the radicle outside seed coat (Wiese and Binning, 1987; Auld et al., 1988). Hard seeds were considered to be those that had not germinated and remained rigid and free of visible contamination at the end of 21 days, according to the ISTA description of hard seed characteristics. The test was carried out immediately after extraction of seeds from the pods. Hard seeds were considered to be those that had not germinated at the end of the germination test, but that were not mucilaginous or exhibiting signs of fungal infection at the end of the test.

\section{Statistical analysis}

Experiments were laid out in a Randomized Complete Block design with a factorial arrangement using three replications $(n=3)$, with each block being consisting of 12 plots of $9 \mathrm{~m}^{2}(3 \times 3$ $\mathrm{m})$ in a total of 36 plots (10 plants per plot).

Statistical analysis was carried out with the aid of the S.A.S. statistical package (SAS Institute Inc., USA) and means were compared by the Least Significant Difference (LSD) test at $\mathrm{p}<0.05$.

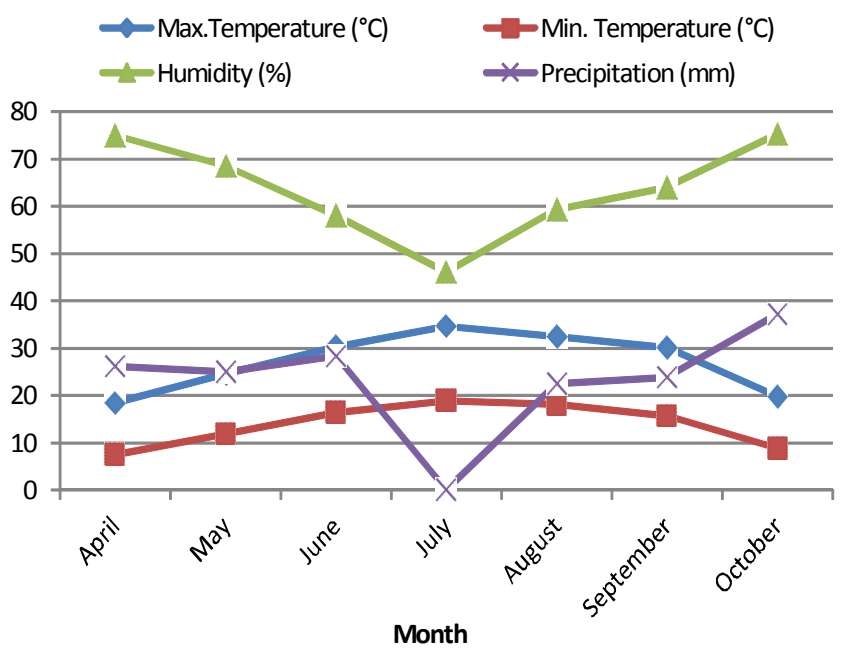

Fig. 1. Climatic conditions during the experiment 
Table 1. The effect of micronutrients on final plant height, seed yield, total flower induction and pod set

\begin{tabular}{lccccc}
\hline $\begin{array}{l}\text { Cultivar } \\
(\mathrm{C})^{\mathrm{z}}\end{array}$ & $\begin{array}{c}\text { Micronutrie } \\
\text { nt level }(\mathrm{M})\end{array}$ & $\begin{array}{c}\text { Plant } \\
\text { height }(\mathrm{cm})\end{array}$ & $\begin{array}{c}\text { Seed yield } \\
(\mathrm{kg} / \mathrm{ha})\end{array}$ & $\begin{array}{c}\text { Total flower } \\
\text { induction } \\
\text { (flowers/plant) }\end{array}$ & $\begin{array}{c}\text { Pod set } \\
\text { (pods/plant) }\end{array}$ \\
\hline $\mathrm{B}$ & $\mathrm{M}_{1}$ & $98.0^{\mathrm{b}}$ & $1506.8^{\mathrm{a}}$ & $20.8^{\mathrm{a}}$ & $18.8^{\mathrm{a}}$ \\
& $\mathrm{M}_{2}$ & $113.0^{\mathrm{a}}$ & $1327.0^{\mathrm{b}}$ & $19.3^{\mathrm{a}}$ & $17.0^{\mathrm{a}}$ \\
& $\mathrm{M}_{3}$ & $106.0^{\mathrm{b}}$ & $1312.0^{\mathrm{b}}$ & $17.9^{\mathrm{a}}$ & $15.8^{\mathrm{a}}$ \\
$\mathrm{V}$ & $\mathrm{M}_{1}$ & $133.0^{\mathrm{a}}$ & $1526.8^{\mathrm{b}}$ & $18.5^{\mathrm{a}}$ & $16.5^{\mathrm{b}}$ \\
& $\mathrm{M}_{2}$ & $103.0^{\mathrm{b}}$ & $1451.8^{\mathrm{b}}$ & $20.6^{\mathrm{a}}$ & $19.0^{\mathrm{b}}$ \\
& $\mathrm{M}_{3}$ & $140.0^{\mathrm{a}}$ & $1903.0^{\mathrm{a}}$ & $22.0^{\mathrm{a}}$ & $20.5^{\mathrm{a}}$ \\
$\mathrm{P}$ & $\mathrm{M}_{1}$ & $103.0^{\mathrm{b}}$ & $1611.7^{\mathrm{b}}$ & $15.1^{\mathrm{b}}$ & $14.2^{\mathrm{b}}$ \\
& $\mathrm{M}_{2}$ & $114.0^{\mathrm{a}}$ & $1701.6^{\mathrm{b}}$ & $18.9^{\mathrm{a}}$ & $17.5^{\mathrm{ab}}$ \\
& $\mathrm{M}_{3}$ & $110.0^{\mathrm{ab}}$ & $1868.1^{\mathrm{a}}$ & $20.9^{\mathrm{a}}$ & $19.2^{\mathrm{a}}$ \\
$\mathrm{Cl}$ & $\mathrm{M}_{1}$ & $79.0^{\mathrm{a}}$ & $2727.2^{\mathrm{a}}$ & $25.2^{\mathrm{a}}$ & $23.7^{\mathrm{a}}$ \\
& $\mathrm{M}_{2}$ & $72.0^{\mathrm{ab}}$ & $2745.5^{\mathrm{a}}$ & $24.4^{\mathrm{a}}$ & $23.0^{\mathrm{a}}$ \\
\hline $\mathrm{C} \times \mathrm{M}$ & $\mathrm{M}_{3}$ & $64.0^{\mathrm{b}}$ & $2206.1^{\mathrm{b}}$ & $22.8^{\mathrm{a}}$ & $21.4^{\mathrm{a}}$ \\
$\left(\mathrm{C} \times \mathrm{M}_{1}\right)$ & & $*$ & $*$ & $*$ & $*$ \\
$\left(\mathrm{C} \times \mathrm{M}_{2}\right)$ & & $*$ & $*$ & $*$ & $*$ \\
$\left(\mathrm{C} \times \mathrm{M}_{3}\right)$ & & $*$ & $*$ & $*$ & $*$ \\
\hline
\end{tabular}

Mean separation by LSD test. Mean values for each cultivar individually in the same column followed by different letters without parenthesis differ significantly at $\mathrm{P}=0.05$; letters in parenthesis refer to horizontal analysis of the means; ${ }^{¥}$ B: 'Boyatiou', V: 'Veloudo', P: 'Pylaias', Cl: ‘Clemson'; $\mathrm{M}_{1}=$ control (0 $\mathrm{ml}$ of micro fertilizer); $\mathrm{M}_{2}=40 \mathrm{ml}$ micro fertilizer $\left(20 \mathrm{ml}\right.$ of fertilizers $F_{1}$ and $F_{2}$ ); $\mathrm{M}_{3}=80 \mathrm{ml}$ micro fertilizer $\left(40 \mathrm{ml}\right.$ of fertilizers $\mathrm{F}_{1}$ and $\left.\mathrm{F}_{2}\right)$; *: statistically significant $(p<0.05)$

\section{Results}

\section{Effect of micronutrients on plant growth}

Micronutrient application had a variable effect on plant height depending on the cultivar (Table 1). In 'Boyiatiou' and 'Pylaias' micronutrient application increased plant height, whereas in 'Clemson' and 'Veloudo' had either no effect or reduced plant height.

The total number of flowers formed on each plant was not affected by micronutrient application, except in cv. 'Pylaias', where flower induction was higher at both micronutrient levels $\left(\mathrm{M}_{2}\right.$ and $\left.\mathrm{M}_{3}\right)$ compared with the control $\left(\mathrm{M}_{1}\right)$ (Table 1$)$. Pod set was not affected by micronutrients in 'Boyiatiou' and 'Clemson', but was increased in 'Veloudo' and 'Pylaias' (Table 1).

Mean pod length differed between the cultivars, whereas there was no effect of micronutrient levels on the pod length and diameter of any cultivar, irrespective of the position of the pod on the plant at harvest (Table 2). There were also virtually no differences in pod length and diameter between pods harvested from different positions on the plant.

In all treatments, pod diameter decreased with increasing DAA. Pod length also decreased in pods harvested between 30 and $50 \mathrm{DAA}$, but not always to a statistically significant level (Table 3). There was also no consistent effect of micronutrients on pod length and diameter in relation to harvesting time (Table 3). Thus, pod length tended to be higher at $30 \mathrm{DAA}$ in 'Boyiatiou', 'Veloudo' and 'Pylaias' following micronutrient application, but to a lesser extent on subsequent days. On the other hand pod diameter of these three cultivars was lower at 30 DAA following micronutrient application, but tended not to differ at subsequent harvest dates (Table 3 ).

\section{Effect of micronutrients on seed characteristics}

Micronutrients had a variable effect on seed yield depending on the cultivar and micronutrient application treatment, as shown in Table 1. Moreover, it was observed that flower initiation in all cultivars was highest at temperatures of about 36 ${ }^{\circ} \mathrm{C}$, whereas at higher or lower temperatures flower initiation decreased (data not shown).

The study of the effect of micronutrient levels on the number of seeds per pod showed that in all cultivars except 'Boyiatiou' there was a significant difference in the number of seeds per pod and the micronutrient level (Table 4). These differences, however, were not consistent.

Similarly, when seed number was measured in relation to harvesting time, it was found that the number of seeds per pod varied considerably both with the level of micronutrient application and the number of days after anthesis that pods were harvested (Table 5). In all cases, the number of seeds per pod was lower for treatment $\mathrm{M}_{3}$ at $50 \mathrm{DAA}$ than in $\mathrm{M}_{1}$ (control). This was also the case for pods harvested at 40 DAA (except 'Boyiatiou').

When seed number was recorded in relation to the position of the pods on the plant, it was found that for the early-formed pods (those at the lower position on the plant) there was no effect of micronutrients on seed number (Table 4), whereas for pods formed in the middle and higher parts of the plant there were differences between the treatments.

Table 2. The effect of micronutrients on the dimensions of pods harvested at seed maturity from different positions on the plant (upper, middle,

lower part)

\begin{tabular}{|c|c|c|c|c|c|c|c|}
\hline \multirow{2}{*}{ Cultivar $(C)^{Y}$} & \multirow{2}{*}{$\begin{array}{l}\text { Micronutrients } \\
\text { level (M) }\end{array}$} & \multicolumn{3}{|c|}{ Pod length $(\mathrm{cm})$} & \multicolumn{3}{|c|}{ Pod diameter $(\mathrm{cm})$} \\
\hline & & $\mathrm{U}$ & $\mathrm{M}$ & $\mathrm{L}$ & $\mathrm{U}$ & $\mathrm{M}$ & $\mathrm{L}$ \\
\hline \multirow{3}{*}{ B } & $\mathrm{M}_{1}$ & $15.6^{a(c)}$ & $17.0^{2(a)}$ & $16.3^{\mathrm{ab}(\mathrm{b})}$ & $2.2^{a(b)}$ & $2.2^{\mathrm{ab}(\mathrm{b})}$ & $2.5^{a(2)}$ \\
\hline & $\mathrm{M}_{2}$ & $15.2^{a(b)}$ & $16.9^{a^{(a)}}$ & $15.7^{\mathrm{b}^{(\mathrm{b})}}$ & $2.3^{a(b)}$ & $2.4^{a(a b)}$ & $2.5^{a(a)}$ \\
\hline & $\mathrm{M}_{3}$ & $15.4^{a(b)}$ & $17.6^{a(a)}$ & $17.1^{(a)}$ & $2.1^{a(b)}$ & $2.1^{\mathrm{b}(\mathrm{b})}$ & $2.4^{(a)}$ \\
\hline \multirow{3}{*}{ V } & $\mathrm{M}_{1}$ & $22.0^{a(a)}$ & $19.8^{\mathrm{a}(\mathrm{b})}$ & $21.1^{a(a b)}$ & $2.2^{2(2)}$ & $2.1^{1(a)}$ & $2.2^{2(a)}$ \\
\hline & $\mathrm{M}_{2}$ & $22.0^{a(a)}$ & $20.7^{\mathrm{a}(\mathrm{b})}$ & $22.1^{(2 a)}$ & $2.1^{1(2)}$ & $2.1^{\mathrm{a}(\mathrm{a})}$ & $2.2^{(a)}$ \\
\hline & $\mathrm{M}_{3}$ & $20.7^{\mathrm{b}(\mathrm{b})}$ & $21.2^{\mathrm{a}(\mathrm{ab})}$ & $22.7^{(a)}$ & $2.1^{1(2)}$ & $2.1^{\mathrm{a}(\mathrm{a})}$ & $2.2^{2(a)}$ \\
\hline \multirow{3}{*}{$\mathrm{P}$} & $\mathrm{M}_{1}$ & $22.4^{a(a)}$ & $21.0^{a(\mathrm{ab})}$ & $19.4^{(b)}$ & $2.3^{a(2)}$ & $2.2^{a(a)}$ & $2.2^{\mathrm{ab}(\mathrm{a}}$ \\
\hline & $\mathrm{M}_{2}$ & $22.2^{a(a)}$ & $20.4^{\mathrm{a}^{(\mathrm{b})}}$ & $21.6^{a(a b)}$ & $2.3^{\mathrm{a}(\mathrm{a})}$ & $2.1^{\mathrm{a}(\mathrm{a})}$ & $2.4^{(a)}$ \\
\hline & $\mathrm{M}_{3}$ & $22.2^{a(a)}$ & $20.6^{a(a)}$ & $21.2^{\mathrm{ab}(\mathrm{a})}$ & $2.2^{2(a)}$ & $2.2^{a(a)}$ & $2.0^{b(a)}$ \\
\hline \multirow{3}{*}{$\mathrm{Cl}$} & $\mathrm{M}_{1}$ & $19.4^{a(a)}$ & $19.4^{\mathrm{ab}(\mathrm{a})}$ & $18.5^{2^{(a)}}$ & $1.5^{\mathrm{a}(\mathrm{a})}$ & $1.4^{a(a)}$ & $1.5^{a(a)}$ \\
\hline & $\mathrm{M}_{2}$ & $19.6^{a(a)}$ & $19.9^{9^{(a)}}$ & $17.9^{9^{(b)}}$ & $1.5^{a(a)}$ & $1.4^{\mathrm{a}(\mathrm{a})}$ & $1.5^{a(a)}$ \\
\hline & $\mathrm{M}_{3}$ & $19.3^{a(a)}$ & $18.7^{\mathrm{b}(\mathrm{a})}$ & $18.2^{2^{(a)}}$ & $1.4^{(2(a)}$ & $1.5^{\mathrm{a}(\mathrm{a})}$ & $1.6^{(a)}$ \\
\hline \multicolumn{8}{|l|}{$\mathrm{C} \times \mathrm{M}$} \\
\hline$\left(\mathrm{C} \times \mathrm{M}_{1}\right)$ & & * & * & * & * & * & * \\
\hline$\left(\mathrm{C} \times \mathrm{M}_{2}\right)$ & & * & * & * & * & * & * \\
\hline$\left(\mathrm{C} \mathrm{M}_{3}\right)$ & & * & $*$ & $*$ & $*$ & * & $*$ \\
\hline
\end{tabular}

Mean separation by LSD test. Mean values for each cultivar individually in the same column followed by different letters without parenthesis differ significantly at $\mathrm{P}=$ 0.05; letters in parenthesis refer to horizontal analysis of the means; ${ }^{Y} \mathrm{~B}$ : 'Boyatiou', V: 'Veloudo', P: 'Pylaias', Cl: 'Clemson'; U: upper part, M: middle part, L: lower part; $\mathrm{M}_{1}=\mathrm{control}\left(0 \mathrm{ml}\right.$ of micro fertilizer); $\mathrm{M}_{2}=40 \mathrm{ml}$ micro fertilizer $\left(20 \mathrm{ml}\right.$ of fertilizers $\mathrm{F}_{1}$ and $\left.\mathrm{F}_{2}\right) ; \mathrm{M}_{3}=80 \mathrm{ml} \mathrm{micro} \mathrm{fertilizer}\left(40 \mathrm{ml}\right.$ of fertilizers $\mathrm{F}_{1}$ and $\left.\mathrm{F}_{2}\right) ;$ * statistically significant $(\mathrm{p}<0.05)$. 
Table 3. The effect of micronutrients on the dimensions of pods harvested on different days after anthesis (DAA)

\begin{tabular}{|c|c|c|c|c|c|c|c|c|c|}
\hline \multirow{3}{*}{$\begin{array}{l}\text { Cultivar } \\
(\mathrm{C})^{¥}\end{array}$} & \multirow{3}{*}{$\begin{array}{l}\text { Micronutrients } \\
\text { level (M) }\end{array}$} & \multicolumn{4}{|c|}{ Pod length $(\mathrm{cm})$} & \multicolumn{4}{|c|}{ Pod diameter $(\mathrm{cm})$} \\
\hline & & 30 & 35 & 40 & 50 & 30 & 35 & 40 & 50 \\
\hline & & DAA & DAA & DAA & DAA & DAA & DAA & DAA & DAA \\
\hline \multirow{3}{*}{ B } & $\mathrm{M}_{1}$ & $16.7^{\mathrm{b}(\mathrm{ab})}$ & $16.8^{\mathrm{a}(\mathrm{a})}$ & $16.0^{\mathrm{ab}(\mathrm{bc})}$ & $15.8^{\mathrm{ab}(\mathrm{c})}$ & $2.6^{a(a)}$ & $2.6^{\mathrm{a}(\mathrm{a})}$ & $2.3^{\mathrm{a}(\mathrm{b})}$ & $1.9^{\mathrm{b}(\mathrm{c})}$ \\
\hline & $\mathrm{M}_{2}$ & $16.3^{\mathrm{b}(\mathrm{ab})}$ & $16.5^{\mathrm{a}(\mathrm{a})}$ & $15.9^{\mathrm{b}(\mathrm{ab})}$ & $15.2^{\mathrm{b}(\mathrm{b})}$ & $2.6^{a(a)}$ & $2.6^{a(a)}$ & $2.2^{\mathrm{ab}(\mathrm{b})}$ & $2.1^{a(b)}$ \\
\hline & $\mathrm{M}_{3}$ & $18.0^{\mathrm{a}(\mathrm{a})}$ & $16.4^{\mathrm{a}(\mathrm{b})}$ & $16.3^{\mathrm{a}(\mathrm{b})}$ & $16.1^{\mathrm{a}(\mathrm{b})}$ & $2.3^{\mathrm{b}(\mathrm{ab})}$ & $2.5^{\mathrm{a}(\mathrm{a})}$ & $2.1^{\mathrm{b}(\mathrm{bc})}$ & $1.9^{\mathrm{b}(\mathrm{c})}$ \\
\hline \multirow{3}{*}{ V } & $\mathrm{M}_{1}$ & $20.7^{\mathrm{b}(\mathrm{ab})}$ & $21.5^{\mathrm{a}(\mathrm{ab})}$ & $21.8^{\mathrm{b}(\mathrm{a})}$ & $19.9^{\mathrm{ab}(\mathrm{b})}$ & $2.4^{a(a)}$ & $2.1^{\mathrm{a}(\mathrm{b})}$ & $2.4^{\mathrm{a}(\mathrm{a})}$ & $1.8^{\mathrm{b}(\mathrm{c})}$ \\
\hline & $\mathrm{M}_{2}$ & $23.0^{\mathrm{a}(\mathrm{a})}$ & $20.2^{\mathrm{a}(\mathrm{b})}$ & $22.4^{\mathrm{a}(\mathrm{a})}$ & $20.7^{\mathrm{a}(\mathrm{b})}$ & $2.4^{\mathrm{a}(\mathrm{a})}$ & $2.0^{\mathrm{a}(\mathrm{c})}$ & $2.2^{\mathrm{b}(\mathrm{b})}$ & $1.9^{\mathrm{a}(\mathrm{c})}$ \\
\hline & $\mathrm{M}_{3}$ & $22.1^{a(a)}$ & $21.4^{\mathrm{a}(\mathrm{a})}$ & $22.9^{a(a)}$ & $19.8^{\mathrm{b}(\mathrm{b})}$ & $2.3^{\mathrm{b}(\mathrm{a})}$ & $2.2^{\mathrm{a}(\mathrm{a})}$ & $2.3^{\mathrm{b}(\mathrm{a})}$ & $1.7^{\mathrm{c}(\mathrm{b})}$ \\
\hline \multirow{3}{*}{$\mathrm{P}$} & $\mathrm{M}_{1}$ & $20.7^{\mathrm{b}(\mathrm{a})}$ & $20.1^{\mathrm{a}(\mathrm{a})}$ & $22.2^{\mathrm{a}(\mathrm{a})}$ & $20.6^{\mathrm{ab}(\mathrm{a})}$ & $2.6^{a(a)}$ & $2.6^{\mathrm{b}(\mathrm{a})}$ & $2.1^{\mathrm{a}(\mathrm{b})}$ & $1.7^{\mathrm{a}(\mathrm{c})}$ \\
\hline & $\mathrm{M}_{2}$ & $22.4^{\mathrm{ab}(\mathrm{a})}$ & $20.8^{\mathrm{a}(\mathrm{a})}$ & $21.5^{\mathrm{a}(\mathrm{a})}$ & $20.8^{\mathrm{b}(\mathrm{a})}$ & $2.5^{\mathrm{a}(\mathrm{a})}$ & $2.5^{\mathrm{a}(\mathrm{a})}$ & $2.2^{\mathrm{a}(\mathrm{a})}$ & $1.8^{\mathrm{a}(\mathrm{b})}$ \\
\hline & $\mathrm{M}_{3}$ & $22.8^{\mathrm{a}(\mathrm{a})}$ & $22.1^{\mathrm{a}(\mathrm{a})}$ & $21.7^{\mathrm{a}(\mathrm{ab})}$ & $18.8^{\mathrm{a}(\mathrm{b})}$ & $2.2^{\mathrm{b}(\mathrm{a})}$ & $2.3^{\mathrm{c}(\mathrm{a})}$ & $2.2^{\mathrm{a}(\mathrm{a})}$ & $1.9^{a^{(b)}}$ \\
\hline \multirow{3}{*}{$\mathrm{Cl}$} & $\mathrm{M}_{1}$ & $19.8^{\mathrm{a}(\mathrm{a})}$ & $19.5^{\mathrm{a}(\mathrm{ab})}$ & $19.0^{\mathrm{a}(\mathrm{ab})}$ & $18.2^{\mathrm{a}(\mathrm{b})}$ & $1.7^{\mathrm{a}(\mathrm{a})}$ & $1.6^{\mathrm{b}(\mathrm{a})}$ & $1.4^{\mathrm{b}(\mathrm{b})}$ & $1.2^{\mathrm{a}(\mathrm{c})}$ \\
\hline & $\mathrm{M}_{2}$ & $18.5^{\mathrm{ab}(\mathrm{a})}$ & $19.8^{\mathrm{a}(\mathrm{a})}$ & $20.2^{\mathrm{a}(\mathrm{a})}$ & $18.2^{\mathrm{a}(\mathrm{a})}$ & $1.7^{\mathrm{a}(\mathrm{a})}$ & $1.7^{\mathrm{a}(\mathrm{a})}$ & $1.4^{\mathrm{b}(\mathrm{b})}$ & $1.1^{\mathrm{b}(\mathrm{c})}$ \\
\hline & $\mathrm{M}_{3}$ & $17.6^{\mathrm{b}(\mathrm{b})}$ & $19.0^{\mathrm{a}(\mathrm{ab})}$ & $20.9^{\mathrm{a}(\mathrm{a})}$ & $17.4^{\mathrm{a}(\mathrm{b})}$ & $1.7^{\mathrm{a}(\mathrm{a})}$ & $1.6^{\mathrm{b}(\mathrm{ab})}$ & $1.5^{\mathrm{a}(\mathrm{ab})}$ & $1.1^{\mathrm{b}(\mathrm{c})}$ \\
\hline \multicolumn{10}{|l|}{$\mathrm{C} \times \mathrm{M}$} \\
\hline$\left(\mathrm{C} \times \mathrm{M}_{1}\right)$ & & * & * & * & * & * & * & * & * \\
\hline$\left(\mathrm{C} \times \mathrm{M}_{2}\right)$ & & * & * & * & * & * & * & * & * \\
\hline$\left(\mathrm{C} \times \mathrm{M}_{3}\right)$ & & * & $*$ & * & $*$ & $*$ & * & $*$ & * \\
\hline
\end{tabular}

Mean separation by LSD test. Mean values for each cultivar individually in the same column followed by different letters without parenthesis differ significantly at $\mathrm{P}=$ 0.05 ; letters in parenthesis refer to horizontal analysis of the means; ${ }^{¥} \mathrm{~B}$ : 'Boyatiou', V: 'Veloudo', P: 'Pylaias', Cl: ‘Clemson'; $\mathrm{M}_{1}=\mathrm{control}(0 \mathrm{ml}$ of micro fertilizer $)$; M $\mathrm{C}_{2}=$ $40 \mathrm{ml}$ micro fertilizer $\left(20 \mathrm{ml}\right.$ of fertilizers $\mathrm{F}_{1}$ and $\left.\mathrm{F}_{2}\right) ; \mathrm{M}_{3}=80 \mathrm{ml}$ micro fertilizer $\left(40 \mathrm{ml}\right.$ of fertilizers $\mathrm{F}_{1}$ and $\left.\mathrm{F}_{2}\right)$; * : statistically significant $(\mathrm{p}<0.05)$.

Table 4. The effect of micronutrients on seed characteristics at seed maturity and the number of seed per pod in relation to plant part (upper, middle, lower)

\begin{tabular}{|c|c|c|c|c|c|c|}
\hline \multirow{2}{*}{$\begin{array}{l}\text { Cultivar } \\
(\mathrm{C})^{\mp}\end{array}$} & \multirow{2}{*}{$\begin{array}{l}\text { Micronutrients } \\
\text { level(M) }\end{array}$} & \multirow{2}{*}{$\begin{array}{c}\text { Number of seeds } \\
\text { perpod }\end{array}$} & \multirow{2}{*}{$\begin{array}{r}100 \text { seed } \\
\text { weight }(\mathrm{g})\end{array}$} & \multicolumn{3}{|c|}{$\begin{array}{c}\text { Number } \\
\text { ofseedsperpod }\end{array}$} \\
\hline & & & & $\mathrm{U}$ & $\mathrm{M}$ & $\mathrm{L}$ \\
\hline \multirow{3}{*}{ B } & $\mathrm{M}_{1}$ & $66.0^{\mathrm{a}}$ & $7.3^{\mathrm{a}}$ & $69.2^{\mathrm{a}(\mathrm{a})}$ & $70.7^{\mathrm{a}(\mathrm{a})}$ & $58.6^{\mathrm{a}(\mathrm{b})}$ \\
\hline & $\mathrm{M}_{2}$ & $63.4^{\mathrm{a}}$ & $7.4^{\mathrm{a}}$ & $66.6^{a(a)}$ & $67.0^{\mathrm{b}(\mathrm{a})}$ & $56.6^{a(b)}$ \\
\hline & $\mathrm{M}_{3}$ & $66.5^{\mathrm{a}}$ & $7.5^{\mathrm{a}}$ & $67.7^{\mathrm{a}(\mathrm{a})}$ & $70.6^{a(a)}$ & $61.1^{\mathrm{a}(\mathrm{b})}$ \\
\hline \multirow{3}{*}{ V } & $\mathrm{M}_{1}$ & $63.2^{\mathrm{a}}$ & $8.8^{\mathrm{a}}$ & $71.2^{\mathrm{a}(\mathrm{a})}$ & $55.5^{\mathrm{a}(\mathrm{b})}$ & $62.0^{\mathrm{a}(\mathrm{ab})}$ \\
\hline & $\mathrm{M}_{2}$ & $53.4^{\mathrm{b}}$ & $8.6^{\mathrm{a}}$ & $56.7^{\mathrm{b}(\mathrm{a})}$ & $52.5^{\mathrm{a}(\mathrm{a})}$ & $51.1^{\mathrm{a}(\mathrm{a})}$ \\
\hline & $\mathrm{M}_{3}$ & $66.4^{a}$ & $8.4^{\mathrm{a}}$ & $73.7^{\mathrm{a}(\mathrm{a})}$ & $62.5^{\mathrm{a}(\mathrm{b})}$ & $63.1^{\mathrm{a}(\mathrm{b})}$ \\
\hline \multirow{3}{*}{ P } & $\mathrm{M}_{1}$ & $79.3^{\mathrm{a}}$ & $8.6^{\mathrm{a}}$ & $84.5^{\mathrm{a}(\mathrm{a})}$ & $78.4^{\mathrm{ab}(\mathrm{a})}$ & $75.2^{\mathrm{a}(\mathrm{a})}$ \\
\hline & $\mathrm{M}_{2}$ & $64.9^{c}$ & $9.0^{\mathrm{a}}$ & $67.5^{\mathrm{b}(\mathrm{a})}$ & $68.1^{\mathrm{b}(\mathrm{a})}$ & $59.3^{(a) a)}$ \\
\hline & $\mathrm{M}_{3}$ & $68.8^{\mathrm{b}}$ & $8.5^{\mathrm{a}}$ & $60.0^{\mathrm{b}(\mathrm{b})}$ & $84.3^{\mathrm{a}(\mathrm{a})}$ & $62.2^{a(b)}$ \\
\hline \multirow{3}{*}{$\mathrm{Cl}$} & $\mathrm{M}_{1}$ & $86.4^{\mathrm{ab}}$ & $8.0^{\mathrm{a}}$ & $101.2^{\mathrm{a}(\mathrm{a})}$ & $87.0^{b(a b)}$ & $71.0^{\mathrm{a}(\mathrm{b})}$ \\
\hline & $\mathrm{M}_{2}$ & $90.8^{\mathrm{a}}$ & $7.9^{\mathrm{a}}$ & $90.0^{\mathrm{b}(\mathrm{a})}$ & $97.7^{\mathrm{a}(\mathrm{a})}$ & $84.6^{\mathrm{a}(\mathrm{a})}$ \\
\hline & $\mathrm{M}_{3}$ & $78.4^{\mathrm{b}}$ & $7.9^{\mathrm{a}}$ & $86.2^{\mathrm{b}(\mathrm{a})}$ & $73.0^{c(\mathrm{a})}$ & $76.0^{2(a)}$ \\
\hline \multicolumn{7}{|l|}{$\mathrm{C} \times \mathrm{X}$} \\
\hline$\left(\mathrm{C} \times \mathrm{M}_{1}\right)$ & & * & * & * & * & ns \\
\hline$\left(\mathrm{C} \times \mathrm{M}_{2}\right)$ & & * & * & * & * & * \\
\hline$\left(\mathrm{C} \times \mathrm{M}_{3}\right)$ & & * & ns & * & * & ns \\
\hline
\end{tabular}

Mean separation by LSD test. Mean values for each cultivar individually in the same column followed by different letters without parenthesis differ significantly at $\mathrm{P}=0.05$; letters in parenthesis refer to horizontal analysis of the means; ${ }^{\mathrm{Y}} \mathrm{B}$ : 'Boyatiou', V: 'Veloudo', P: 'Pylaias', Cl: ‘Clemson'; U: upper part, M: middle part, L: lower part; $\mathrm{M}_{1}=$ control $(0 \mathrm{ml}$ of micro fertilizer $) ; \mathrm{M}_{2}=40 \mathrm{ml}$ micro fertilizer $\left(20 \mathrm{ml}\right.$ of fertilizers $F_{1}$ and $\left.F_{2}\right) ; M_{3}=80 \mathrm{ml}$ micro fertilizer $(40 \mathrm{ml}$ of fertilizers $F_{1}$ and $\left.F_{2}\right) ;{ }^{*}$ : statistically significant $(p<0.05)$; ns: not significant.

Seed size (i.e. 100 seed weight) was higher in 'Veloudo' and 'Pylaias' than in 'Boyiatiou' and 'Clemson', but was not affected by the micronutrient level in any of the cultivars (data not shown). The mean 100 seed weight decreased significantly at 50 DAA in all cultivars and treatments (Table 5) but was not affected by the position of the pod on the plant, irrespective of cultivar and micronutrient level (data not shown).

The moisture content of seeds at harvest (pooled data for the whole plant) ranged from $33-37 \%$ and was not affected by micronutrient level in any of the four cultivars (data not shown). Seeds harvested at 40-50 DAA had significantly lower moisture content than those harvested at 30-35 DAA. Moreover, at the later harvest dates, the moisture content of seeds from the higher micronutrient level $\left(\mathrm{M}_{3}\right)$ was higher than control $\left(\mathrm{M}_{1}\right)$ (data not sown), whereas there was no apparent effect of micronutrients on the moisture content of seeds from fruits from different plant parts (data not shown).

Seed hardness was highest in 'Boyiatiou' and lowest in 'Clemson' (data not shown). The application of micronutrients appeared to reduce the percentage of hard seeds in Boyiatiou, but had less or no effect on seeds of the other cultivars. As shown in Table 6, seed hardness did not occur in any cultivar when pods were harvested at 30-35 DAA, while at later stages tended to increase, especially at 50 DAA.

Seed germination of all cultivars was positively affected by the application of micronutrient, with germination being significantly lower when no micronutrients were applied (control; $\mathrm{M}_{1}$ ) and highest at $\mathrm{M}_{3}$ level for cv. 'Boyiatiou' and 'Veloudo' or at both levels $\left(\mathrm{M}_{2}\right.$ and $\left.\mathrm{M}_{3}\right)$ for 'Pylaias' and 'Clemson' (data not shown).

When germination was recorded at different dates of harvest, it was found that in fruits harvested at 40-50 DAA germination was highest at the higher micronutrient level $\left(\mathrm{M}_{3}\right)$, although not always to a statistically significant level (Table 6). A similar trend was also observed for fruits harvested at 30-35 DAA, but to a statistically significant level only in cv. 'Veloudo'.

When comparing pods harvested from different parts of the plant, it was found that in all cultivars seed germination was increased by micronutrient application irrespective of the position of the pod on the plant at harvest (Table 6). When comparing cultivars, 'Clemson' had the highest percent germination irrespective of the position of the pod on the plant and the time of harvest, whereas 'Boyiatiou had the lowest germination in relation to time of harvest and 'Veloudo' with respect to pod position, but without statistically significant differences between the two (Table 6).

\section{Discussion}

\section{Effect of micronutrients}

Foliar application of micronutrients increased plant growth (plant height) only of cv. 'Boyiatiou' and 'Pylaias' (Table 1). In 
Table 5. The effect of micronutrients on seed characteristics of pods harvested at different days after anthesis (DAA)

\begin{tabular}{|c|c|c|c|c|c|c|c|c|c|}
\hline \multirow{3}{*}{$\begin{array}{l}\text { Cultivar } \\
(\mathrm{C})^{¥}\end{array}$} & \multirow{3}{*}{$\begin{array}{l}\text { Micronutrients } \\
\text { level (M) }\end{array}$} & \multicolumn{4}{|c|}{ Number of seeds per pod } & \multicolumn{4}{|c|}{100 seed weight $(\mathrm{g})$} \\
\hline & & 30 & 35 & 40 & 50 & 30 & 35 & 40 & 50 \\
\hline & & DAA & DAA & DAA & DAA & DAA & DAA & DAA & DAA \\
\hline \multirow{3}{*}{ B } & $\mathrm{M}_{1}$ & $67.5^{\mathrm{b}(\mathrm{a})}$ & $68.3^{\mathrm{a}(\mathrm{a})}$ & $66.1^{\mathrm{a}(\mathrm{a})}$ & $69.6^{a(a)}$ & $6.5^{\mathrm{a}(\mathrm{b})}$ & $8.7^{\mathrm{a}(\mathrm{a})}$ & $9.4^{\mathrm{b}(\mathrm{a})}$ & $4.8^{\mathrm{b}(\mathrm{c})}$ \\
\hline & $\mathrm{M}_{2}$ & $71.6^{\mathrm{a}(\mathrm{a})}$ & $68.6^{a(a)}$ & $67.2^{\mathrm{a}(\mathrm{a})}$ & $70.3^{a(a)}$ & $6.4^{\mathrm{a}(\mathrm{b})}$ & $8.8^{\mathrm{a}(\mathrm{a})}$ & $9.0^{\mathrm{b}(\mathrm{a})}$ & $4.8^{\mathrm{ab}(\mathrm{b})}$ \\
\hline & $\mathrm{M}_{3}$ & $64.2^{\mathrm{b}(\mathrm{a})}$ & $65.0^{\mathrm{a}(\mathrm{a})}$ & $58.8^{\mathrm{a}(\mathrm{a})}$ & $47.1^{\mathrm{b}(\mathrm{b})}$ & $6.4^{\mathrm{a}(\mathrm{b})}$ & $9.2^{\mathrm{a}(\mathrm{a})}$ & $10.0^{a(a)}$ & $5.0^{\mathrm{a}(\mathrm{c})}$ \\
\hline \multirow{3}{*}{ V } & $\mathrm{M}_{1}$ & $58.2^{\mathrm{c}(\mathrm{a})}$ & $65.3^{\mathrm{a}(\mathrm{a})}$ & $73.6^{\mathrm{a}(\mathrm{a})}$ & $71.3^{\mathrm{a}(\mathrm{a})}$ & $8.0^{\mathrm{a}(\mathrm{b})}$ & $10.7^{\mathrm{a}(\mathrm{a})}$ & $11.3^{\mathrm{a}(\mathrm{a})}$ & $5.6^{a(c)}$ \\
\hline & $\mathrm{M}_{2}$ & $71.6^{\mathrm{a}(\mathrm{a})}$ & $70.3^{\mathrm{a}(\mathrm{a})}$ & $48.7^{b(b)}$ & $36.6^{\mathrm{b}(\mathrm{c})}$ & $7.6^{a(b)}$ & $9.7^{\mathrm{b}(\mathrm{a})}$ & $11.2^{\mathrm{a}(\mathrm{a})}$ & $5.8^{\mathrm{a}(\mathrm{c})}$ \\
\hline & $\mathrm{M}_{3}$ & $66.9^{\mathrm{b}(\mathrm{a})}$ & $71.0^{\mathrm{a}(\mathrm{a})}$ & $50.3^{\mathrm{b}(\mathrm{b})}$ & $46.7^{\mathrm{b}(\mathrm{b})}$ & $7.0^{\mathrm{a}(\mathrm{b})}$ & $10.3^{\mathrm{ab}(\mathrm{a})}$ & $10.8^{\mathrm{b}(\mathrm{a})}$ & $5.7^{\mathrm{a}(\mathrm{c})}$ \\
\hline \multirow{3}{*}{$\mathrm{P}$} & $\mathrm{M}_{1}$ & $66.6^{\mathrm{c}(\mathrm{b})}$ & $71.0^{\mathrm{b}(\mathrm{a})}$ & $67.3^{\mathrm{a}(\mathrm{b})}$ & $77.6^{a(a)}$ & $8.0^{\mathrm{a}(\mathrm{b})}$ & $10.1^{\mathrm{a}(\mathrm{a})}$ & $10.5^{\mathrm{b}(\mathrm{a})}$ & $5.9^{a(c)}$ \\
\hline & $\mathrm{M}_{2}$ & $74.3^{\mathrm{b}(\mathrm{b})}$ & $93.3^{\mathrm{a}(\mathrm{a})}$ & $61.5^{\mathrm{a}(\mathrm{b})}$ & $78.6^{\mathrm{a}(\mathrm{b})}$ & $8.1^{\mathrm{a}(\mathrm{b})}$ & $10.6^{\mathrm{a}(\mathrm{a})}$ & $11.4^{a(a)}$ & $5.9^{a(c)}$ \\
\hline & $\mathrm{M}_{3}$ & $90.0^{\mathrm{a}(\mathrm{a})}$ & $75.4^{\mathrm{b}(\mathrm{ab})}$ & $54.5^{\mathrm{b}(\mathrm{bc})}$ & $42.4^{\mathrm{b}(\mathrm{abc})}$ & $6.7^{\mathrm{a}(\mathrm{b})}$ & $10.7^{\mathrm{a}(\mathrm{a})}$ & $11.1^{\mathrm{a}(\mathrm{a})}$ & $5.7^{\mathrm{a}(\mathrm{b})}$ \\
\hline \multirow{3}{*}{$\mathrm{Cl}$} & $\mathrm{M}_{1}$ & $92.0^{\mathrm{b}(\mathrm{ab})}$ & $105.3^{\mathrm{a}(\mathrm{a})}$ & $76.0^{\mathrm{a}(\mathrm{b})}$ & $96.6^{a(a)}$ & $6.8^{\mathrm{a}(\mathrm{b})}$ & $9.9^{\mathrm{a}(\mathrm{a})}$ & $10.2^{\mathrm{a}(\mathrm{a})}$ & $5.1^{\mathrm{a}(\mathrm{c})}$ \\
\hline & $\mathrm{M}_{2}$ & $94.2^{\mathrm{b}(\mathrm{a})}$ & $83.6^{\mathrm{b}(\mathrm{ab})}$ & $76.6^{\mathrm{a}(\mathrm{b})}$ & $89.3^{\mathrm{a}(\mathrm{ab})}$ & $6.9^{\mathrm{a}(\mathrm{b})}$ & $9.7^{\mathrm{a}(\mathrm{a})}$ & $10.1^{\mathrm{a}(\mathrm{a})}$ & $5.0^{a(c)}$ \\
\hline & $\mathrm{M}_{3}$ & $100.3^{\mathrm{a}(\mathrm{a})}$ & $91.7^{\mathrm{b}(\mathrm{a})}$ & $51.8^{\mathrm{b}(\mathrm{b})}$ & $65.0^{\mathrm{b}(\mathrm{c})}$ & $7.0^{\mathrm{a}(\mathrm{b})}$ & $9.7^{\mathrm{a}(\mathrm{a})}$ & $9.8^{\mathrm{a}(\mathrm{a})}$ & $5.3^{\mathrm{a}(\mathrm{c})}$ \\
\hline$\left(\mathrm{C} \times \mathrm{M}_{1}\right)$ & & * & $*$ & * & * & ns & * & * & * \\
\hline$\left(\mathrm{C} \times \mathrm{M}_{2}\right)$ & & * & * & * & * & ns & * & * & * \\
\hline$\left(\mathrm{C} \times \mathrm{M}_{3}\right)$ & & * & * & ns & ns & ns & * & $*$ & $*$ \\
\hline
\end{tabular}

Mean separation by LSD test. Mean values for each cultivar individually in the same column followed by different letters without parenthesis differ significantly at $\mathrm{P}=$ 0.05; letters in parenthesis refer to horizontal analysis of the means; ' $\mathrm{B}$ : 'Boyatiou', V: 'Veloudo', P: 'Pylaias', Cl: 'Clemson'; $\mathrm{Ml}_{1}=\mathrm{control}(0 \mathrm{ml}$ of micro fertilizer); $\mathrm{M} 2=$ $40 \mathrm{ml}$ micro fertilizer $\left(20 \mathrm{ml}\right.$ of fertilizers $\mathrm{F}_{1}$ and $\left.\mathrm{F}_{2}\right) ; \mathrm{M}_{3}=80 \mathrm{ml}$ micro fertilizer $\left(40 \mathrm{ml}\right.$ of fertilizers $\mathrm{F}_{1}$ and $\left.\mathrm{F}_{2}\right)$; ${ }^{*}$ : statistically significant $(\mathrm{p}<0.05)$; ns: not significant.

Table 6. The effect of micronutrients on seed germination percentage $(\mathrm{G})$ and seed hardness $(\mathrm{S})$ in relation to the days after anthesis (DAA) and the plant part (upper, middle, lower)

\begin{tabular}{|c|c|c|c|c|c|c|c|c|c|c|c|c|}
\hline \multirow[b]{2}{*}{$\begin{array}{l}\text { Cultivar } \\
(\mathrm{C})^{¥}\end{array}$} & \multirow[b]{2}{*}{$\begin{array}{c}\text { Micronutrients } \\
\text { level (M) }\end{array}$} & \multicolumn{8}{|c|}{ Germination percentage (G) (\%) and Seed hardness (S) (\%) } & \multicolumn{3}{|c|}{ Germination percentage $(\mathrm{G})(\%)$} \\
\hline & & $\begin{array}{l}\mathrm{G} \\
(30 \mathrm{I}\end{array}$ & & $\begin{array}{l}\text { G } \\
(35 \mathrm{D}\end{array}$ & & $\begin{array}{l}\mathrm{G} \\
(40 \mathrm{I}\end{array}$ & S & $\begin{array}{l}\text { G } \\
(50\end{array}$ & $\begin{array}{l}\text { S } \\
\text { 4) }\end{array}$ & $\mathrm{U}$ & M & $\mathrm{L}$ \\
\hline \multirow{3}{*}{$\mathrm{B}$} & $\mathrm{M}_{1}$ & $35.2^{\mathrm{a}}$ & - & $42.4^{\mathrm{b}}$ & - & $57.2^{\mathrm{b}}$ & 5.0 & $30.6^{\mathrm{b}}$ & 22.0 & $48.0^{\mathrm{b}(\mathrm{a})}$ & $51.8^{\mathrm{b}(\mathrm{a})}$ & $50.2^{\mathrm{b}(\mathrm{a})}$ \\
\hline & $\mathrm{M}_{2}$ & $36.7^{\mathrm{a}}$ & - & $51.2^{\mathrm{a}}$ & - & $60.3^{\mathrm{ab}}$ & 3.0 & $32.4^{\mathrm{b}}$ & 16.0 & $51.3^{\mathrm{ab}(\mathrm{a})}$ & $61.5^{\mathrm{a}(\mathrm{ab})}$ & $69.5^{\mathrm{b}(\mathrm{a})}$ \\
\hline & $\mathrm{M}_{3}$ & $37.6^{\mathrm{a}}$ & - & $48.7^{\mathrm{ab}}$ & - & $63.2^{\mathrm{a}}$ & 2.0 & $37.5^{\mathrm{a}}$ & 22.0 & $71.9^{\mathrm{a}(\mathrm{ab})}$ & $64.3^{a(b)}$ & $83.2^{\mathrm{a}(\mathrm{a})}$ \\
\hline \multirow{3}{*}{ V } & $\mathrm{M}_{1}$ & $39.1^{\mathrm{b}}$ & - & $47.6^{b}$ & - & $64.7^{b}$ & 1.0 & $41.3^{b}$ & 24.0 & $35.0^{\mathrm{b}(\mathrm{b})}$ & $40.3^{\mathrm{b}(\mathrm{ab})}$ & $50.3^{\mathrm{b}(\mathrm{a})}$ \\
\hline & $\mathrm{M}_{2}$ & $41.7^{b}$ & - & $51.8^{\mathrm{ab}}$ & - & $68.4^{\mathrm{ab}}$ & 4.0 & $41.7^{b}$ & 17.0 & $55.4^{\mathrm{a}(\mathrm{a})}$ & $61.3^{\mathrm{a}(\mathrm{a})}$ & $59.2^{\mathrm{b}(\mathrm{a})}$ \\
\hline & $\mathrm{M}_{3}$ & $46.2^{\mathrm{a}}$ & - & $55.1^{a}$ & - & $74.6^{a}$ & 3.0 & $59.8^{a}$ & 15.0 & $60.7^{\mathrm{a}(\mathrm{a})}$ & $64.7^{\mathrm{a}(\mathrm{a})}$ & $71.4^{\mathrm{a}(\mathrm{a})}$ \\
\hline \multirow{3}{*}{ P } & $\mathrm{M}_{1}$ & $48.3^{a}$ & - & $55.7^{\mathrm{a}}$ & - & $76.2^{b}$ & 1.0 & $75.3^{c}$ & 16.0 & $48.3^{\mathrm{b}(\mathrm{a})}$ & $50.5^{\mathrm{b}(\mathrm{a})}$ & $57.7^{\mathrm{b}(\mathrm{a})}$ \\
\hline & $\mathrm{M}_{2}$ & $50.6^{a}$ & - & $56.0^{a}$ & - & $81.3^{b}$ & - & $83.3^{\mathrm{b}}$ & 11.0 & $64.0^{\mathrm{a}(\mathrm{a})}$ & $80.2^{\mathrm{a}(\mathrm{a})}$ & $75.6^{a(a)}$ \\
\hline & $\mathrm{M}_{3}$ & $53.1^{\mathrm{a}}$ & - & $59.5^{a}$ & - & $93.8^{\mathrm{a}}$ & - & $91.7^{\mathrm{a}}$ & 12.0 & $65.0^{\mathrm{a}(\mathrm{a})}$ & $81.5^{\mathrm{a}(\mathrm{a})}$ & $76.9^{a(a)}$ \\
\hline \multirow{3}{*}{$\mathrm{Cl}$} & $\mathrm{M}_{1}$ & $52.8^{\mathrm{a}}$ & - & $60.1^{b}$ & - & $81.7^{\mathrm{a}}$ & 1.0 & $88.2^{\mathrm{b}}$ & 5.0 & $45.9^{\mathrm{b}(\mathrm{a})}$ & $51.7^{\mathrm{b}(\mathrm{a})}$ & $58.7^{\mathrm{b}(\mathrm{a})}$ \\
\hline & $\mathrm{M}_{2}$ & $53.3^{a}$ & - & $70.8^{\mathrm{a}}$ & - & $84.4^{\mathrm{a}}$ & - & $89.8^{\mathrm{ab}}$ & 4.0 & $84.5^{\mathrm{a}(\mathrm{a})}$ & $90.1^{\mathrm{a}(\mathrm{a})}$ & $88.7^{\mathrm{a}(\mathrm{a})}$ \\
\hline & $\mathrm{M}_{3}$ & $54.8^{a}$ & - & $62.7^{\mathrm{ab}}$ & - & $87.4^{\mathrm{a}}$ & - & $93.8^{\mathrm{a}}$ & 3.0 & $83.8^{\mathrm{a}(\mathrm{a})}$ & $93.7^{\mathrm{a}(\mathrm{a})}$ & $91.8^{\mathrm{a}(\mathrm{a})}$ \\
\hline \multicolumn{13}{|l|}{$\mathrm{C} \times \mathrm{M}$} \\
\hline$\left(\mathrm{C} \times \mathrm{M}_{1}\right)$ & & * & & * & & * & & * & & * & * & $*$ \\
\hline$\left(\mathrm{C} \times \mathrm{M}_{2}\right)$ & & * & & * & & * & & * & & $*$ & $*$ & $*$ \\
\hline$\left(\mathrm{C} \times \mathrm{M}_{3}\right)$ & & * & & $*$ & & * & & * & & * & $*$ & $*$ \\
\hline
\end{tabular}

Mean separation by LSD test. Mean values for each cultivar separately in the same column followed by different letters differ significantly at $\mathrm{P}=0.05$. Mean values for each pod character separately within the rows followed by a different letter in parenthesis differ significantly at P=0.05; ' $\mathrm{Y}$ : 'Boyatiou', V: 'Veloudo', P: 'Pylaias', Cl: 'Clemson'; ( $\mathrm{p}<0.05)$; U: upper part, M: middle part, L: lower part; $\mathrm{M}_{1}=$ control ( $0 \mathrm{ml}$ of micro fertilizer); $\mathrm{M}_{2}=40 \mathrm{ml}$ micro fertilizer $\left(20 \mathrm{ml}\right.$ of fertilizers $\mathrm{F}_{1}$ and $\left.\mathrm{F}_{2}\right)$; $\mathrm{M}_{3}$

$=80 \mathrm{ml}$ micro fertilizer $\left(40 \mathrm{ml}\right.$ of fertilizers $\mathrm{F}_{1}$ and $\left.\mathrm{F}_{2}\right) ;^{*}$ : statistically significant.

'Pylaias' too, micronutrient application increased flower induction and pod set, as well as pod set in 'Veloudo' (Table 1). Overall, there was no effect of micronutrient levels on the pod length and diameter of any cultivar, irrespective of cultivar and the position of the pod on the plant at harvest (Table 2), or on seed size (i.e. 100 seed weight) (data not shown). However, micronutrients did affect the number of seeds per pod, causing a reduction in seed number in 'Veloudo', 'Pylaias' and 'Clemson' (Table 4). This effect was observed mainly in pods harvested from the middle and higher parts of the plant, but not in the lower pods (Table 4); it also varied with the time (DAA) of harvest (Table 5).

In all cultivars, micronutrient application had a positive effect on seed germination. This increase in germination coincided with a decrease in the incidence of seed hardness and was apparently independent of the seed moisture content (data not shown).
From the foregoing, it is clear that micronutrient application was beneficial for seed germination, irrespective of cultivar. It was also beneficial for seed yield, but only in 'Pylaias' and 'Veloudo', due primarily to the increase in pod set.

The present results are consistent with those reported in the literature for okra and other crops. For example, Hazra et al. (1987) recorded an increase in plant height of okra cv. 'Pusa Sawani' following foliar application of Fe (0.2\%). Tamilselvi et al. (2002) reported that foliar application of $\mathrm{Fe}$ in combination with other micronutrients ( $\mathrm{Zn}, \mathrm{Cu}, \mathrm{Mn}, \mathrm{B}$ and $\mathrm{Mo}$ ) in a commercial product (Multiplex at $100 \mathrm{ppm}$ ) significantly increased the number of flowers per cluster and the number of fruiting clusters in tomato. Similarly, Suryanarayana and Rao (1981) reported that foliar application of $\mathrm{Fe}$ along with $\mathrm{Zn}, \mathrm{Cu}, \mathrm{Mn}, \mathrm{Mg}, \mathrm{B}$ and $\mathrm{Mo}$ in a chelated form (Agromin) caused a significant increase in the number of fruits per plant in okra cv. 'Pusa Sawani'. Hazra et al. (1987) reported that foliar application of $\mathrm{Cu}$ at $0.2 \%$ increased the number 
262

of pods per plant in okra cv. 'Pusa Sawani', whereas foliar application of $\mathrm{Fe}$ affected fruit length. In conclusion, it appears that micronutrient application is beneficial for pod and seed yield, although for a more critical assessment of the value of each micronutrient further research is required.

Abbasi et al. (2010) reported that although the fruit length of okra varied according to genotype, but was also affected foliar fertilizer application. In our experiment, pod length was higher at 30 DAA in the micronutrient treatments, but not at 35-50 DAA. Pod length and diameter are considered to be genetically determined characteristics in okra (Raji, 1994). Therefore, at maturity, no effect of micronutrient effect on pod dimensions would be expected, while studies that indicate an increase in pod size following fertilizer application refer to immature pods for fresh consumption (Rekoumi etal.,2012).

The positive effect of micronutrients on seed germination is new for okra. In other crops (e.g. pea), micronutrient deficiencies (e.g. $\mathrm{Mn}$ ) are known to cause lesions within the cotyledons in the seed, whereas excessive amounts of nutrients, especially $\mathrm{N}$, may delay seed maturation. Rekoumi et al. (2003) reported that the seed yield of okra cv. 'Boyiatiou' was beneficially affected when plants were fertilized with $150 \mathrm{ppm} \mathrm{N}$. The concentration of $\mathrm{N}, \mathrm{K}$ and $\mathrm{Mg}$ within the seeds was affected by the $\mathrm{N}$ rate, but germination was not affected.

\section{Effect of cultivar on seed characteristics}

As already reported, cv. 'Boyiatiou' is a cultivar that is highly susceptible to seed hardness, a defect that decreases seed germination and therefore seed quality (Demir, 2001; Passam and Polyzou, 1997). The occurrence of hard seeds relates to field temperatures during pod maturation, the rate of seed drying and the cultivar (Demir, 2001; Passam and Rekoumi, 2009; Sajid et al., 2012) and causes a lack of uniformity in seed germination after sowing (Castro et al., 2008). The percent germination of 'Boyiatiou' was lower than that of the other three cultivars in this study at all times of harvest, while the percentage of hard seeds was highest. Both 'Clemson' and 'Pylaias' exhibited a high percent germination at 40-50 DAA $(>80 \%)$, although germination from these cultivars was reduced in the earlier harvests (30-35 DAA) presumably as a result of embryo immaturity (Table 6). Despite its shorter pods, 'Boyiatiou' had a similar number of seeds per pod to 'Pylaias' and Veloudo', but lower than 'Clemson'. Yield differences between cultivars therefore related mainly to pod set (as noted above) and not to pod size.

\section{Effect of harvesting time on seed characteristics}

Seeds of 'Clemson' and 'Pylaias' harvested 40-50 DAA germinated to a high percentage (83-91\%), whereas 'Boyiatiou' did not meet the minimum germination requirement of $65 \%$ for this species at any stage of harvest. Moreover, the decrease in germination at 50 DAA in 'Veloudo' (due to hard seeds) means that to meet the minimum requirement seeds of this cultivar should be harvested 40 DAA. This result suggests that whereas seeds of 'Clemson' and 'Pylaias' are acceptable for market immediately after harvest, seeds of 'Veloudo' and, in particular, 'Boyiatiou' should be stored prior to marketing. Differences in germination in relation to harvest date have been reported before (Demir, 1997) and relate to seed moisture content (El Balla et al., 2011) and embryo maturation.

\section{Effect of plant part (upper, middle and lower part) on seed} characteristics

Seed moisture content and germination were not affected by the position of the pod on the plant at harvest. This result contrasts with the results of Prabhakar et al. (1985) and Yadav and Dhankhar (2001), who reported that seeds harvested from the lower pods germinated better than those from the higher pods, and Malik et al. (2000) who found maximum germination in seeds from pods located in the middle part of the plant. Moisture content affects the incidence of hard seeds and therefore germination (Demir, 2001), accounting for the reduction in germination in seeds of susceptible cultivars at 4050 DAA. In early sowings in Greece, it is likely that pods in the lower region of the plant will mature under somewhat lower temperatures (e.g. June) than those of the middle and higher parts of the plant, and improved germination might be expected comparing to later sowings, where the first-formed pods would be subjected to high temperatures, and the later-formed pods would mature during the cooler period of September-October and therefore have better seed quality (Passam et al., 1998). In conclusion, the effect of pod position is likely to relate to the climatic conditions during the period of pod set and maturation.

\section{Conclusion}

The main value of foliar application of micronutrients is to increase seed quality, i.e. germination. In some cultivars ('Pylaias' and 'Veloudo' here) micronutrients may also increase seed yield by improving pod set. Irrespective of micronutrient application, the occurrence of hard seeds in susceptible cultivars (e.g. 'Boyiatiou' and 'Veloudo') reduces germination, and therefore seed quality.

\section{Acknowledgement}

This work was supported by the National Foundation of Scholarships of Greece.

\section{References}

Abbasi FF, Baloch MA, Zia-ul-hassan Wagan KH, Shah AN, Rajpar I (2010). Growth and yield of okra under foliar application of some new multinutrient fertilizer products. Pakistan Journal of Agriculture, Agricultural Engineering and Veterinary Sciences 26(2):11-18.

Auld DL, Bettis BL, Crock JE, Kephart D (1988) Planting date and temperature effects on germination, and seed yield of chickpea. AgronomyJournal 80:909-914.

Castro MM, Godoy AR, Cardoso I, Ismael A (2008). Okra seed quality as a function of age and fruit post harvest rest. Ciência e Agrotechologia 32(5):1491-1495.

Demir I (1997). Occurrence of hardseededness in relation to seed development in okra (Abelmoschus esculentus (L) Moench). Plant Varieties and Seeds 10:7-13.

Demir I (2001). The effects of heat treatments on hardseedness of serially harvested okra seed lots at optimum and low temperatures. Scientia Horticulturae 89:1-7.

El-Aal FSA, Shaheen AM, Ahmed AA, Mahmoud AR (2010). Effect of foliar application of urea and amino acids mixtures as antioxidants on growth, yield and characteristics of squash. Research Journal of Agriculture and Biological Sciences 6:583-588.

El Balla, MMA, Saidahmed AI, Makkawi M (2011). Effect of moisture content and maturity on hardseededness and germination in okra 
(Abelmoschus esculentus L. Moench). International Journal of Plant Physiology and Biochemistry3(6):102-107.

Fageria NK, Filhoa MPB, Moreirab A, Guimaresa CM (2009). Foliar fertilization of crop plants. Journal of Plant Nutrition 32(6):1044-1064.

Hazra P, Maity TK, Mandal AR (1987). Effect of foliar application of micronutrients on growth and yield of okra (Abelmoschus esculentus $\mathrm{L}$.). Progressive Horticulture 19:219-222.

Hooda RS, Pandita ML (1982). Effect of micronutrients on growth, yield and quality of potato (Solanum tuberosum L.). Haryana Journal of Horticultural Science 11(1-2):102-106.

Husain SA, Shaik M, Rao BVR (1989). Response of chilli (Capsicum annuum $\mathrm{L}$.) to micronutrients. Indian Journal of Agronomy $34(1)$ :117118.

ISTA (2009). International rules for seed testing. Seed Sci. \& Technol. International Seed Testing Association Switzerland.

Majanbu IS, Ogunlela VB, Ahmed MK (1986). Response of two okra varieties to fertilizer: growth and nutrient concentration as influenced by nitrogen and phosphorus application. Fertilizer Research 8:297-306.

Malik YS, Singh N, Nehra BK, Khurana SC, Dahiya MS, Singh N (2000). Okra seed quality as influenced by position of pod on mother plant, ripening stage of pod and ambient storage conditions. Haryana Journal of Horticultural Science 29:229-232

Palaniappan SP, Jeyabal A, Chellaiah S (1999). Response of tomato and chilli to foliar application of speciality fertilizers. Vegetable Science 26(2):198200.

Passam HC, Polyzou P (1997). Improvement of okra seed germination by acid, osmoconditioning and hot water treatments. Plant Varieties and Seeds 10:135-140.

Passam HC, Akoumiankis K, Sarigiannidi A (1998). The effect of time of sowing on the production of okra (Hibiscus esculentus $\mathrm{L}$.) seed in the Mediterranean region. Plant Varieties and Seeds 11:145-150.

Passam HC, Rekoumi K (2009). Okra in Greece. Production and Constraints. In: Dhankhar BS, Singh R(Eds). Okra Handbook: Global Production, Processing and Crop Improvement. HNB Publishing, New Yorkpp 347-359.
Prabhakar BS, Hegde DM, Srinivas K, DoijodeSC (1985). Seed quality and productivity of okra in relation to nodal position of pod. South Indian Horticulture 33(2):115-117.

Raji JA (1994). Field and glass-house screening of okra genotypes for yield and intercropping. Indian Journal of Agricultural Science 64(7):454 458.

Rekoumi K, Moustakas N, Passam H, Akoumianakis K (2003). The effect of nitrogen fertilization on the concentration of inorganic nutrients in okra (Hibiscus esculentus) cr. Boyiatiou. Proceedings of the Greek Society of Horticultural Science, Ioannina, Greece 10:424-426.

Rekoumi K, Karapanos IC, Akoumianakis KA, Passam HC (2012). Nitrogen application affects yield and postharvest quality of okra (Hibiscus esculentus L. cv. 'Boyiatiou'). International Journal of Plant Production 6(1):59-72.

Sajid M, Khan MA, Rab A, Shah SNM, Arif M, Jan I, Hussain Z, Mukhtiar M (2012). Impact of nitrogen and phosphorus on seed yield and yield components of okra cultivars. Journal of Animal and Plant Science 22(3):704707.

Suryanarayana V, RaoSKV (1981). Effect of growth regulators and nutrient sprays on theyield of okra. Vegetable Science 8:12-13.

Tamilselvi P, Vijayakumar RM, Nainar P (2002). Studies on the effect of foliar application of micronutrients on growth and yield of tomato (Lycopersicon esculentum Mill.) Cv. pkm-1. South Indian Horticulture 53:46-51.

Wiese AM, Binning LK (1987). Calculating the threshold temperature of development for weeds. Weed Science 35:177-179.

Yadav SK, Dhankhar BS (1999). Performance of Varsha Uphar cultivar of okra (Abelmoschus esculentus (L.) Moench) as effected by the sowing dates and plant geometry. Vegetable Science 26:180-182.

Zodape ST, Gupta A, Bhandari SC, Rawat US, Chaudhry DR, Eswaran K, Chikara J (2011). Foliar application of seaweed sap as biostimulant for enhancement of yield and quality of tomato (Lycopersicon esculentum Mill.).Journal ofScientific and Industrial Research 70:215-219. 